\title{
Identification and Quantification of the Major Fungitoxic Components of the Brazilian Basil (Ocimum basilicum L.) Essential Oil
}

\author{
Rosimeire C. Barcelos ${ }^{1}$, Gulab N. Jham ${ }^{2}$, Onkar D. Dhingra ${ }^{2}$, Fernanda A. Mendonça ${ }^{3}$ \& Vânia M. M. Valente \\ ${ }^{1}$ Instituto de Química, Departamento de Química Orgânica, Universidade Estadual de Campinas, Campinas, SP, Brazil \\ ${ }^{2}$ Departamento de Fitopatologia, Universidade Federal de Viçosa, Viçosa, MG, Brazil \\ ${ }^{3}$ Departamento de Química, Universidade Federal de Viçosa, Viçosa, MG, Brazil \\ ${ }^{4}$ Departamento de Química, Universidade Federal de Viçosa, Campus Rio Paranaíba, MG, Brazil \\ Correspondence: Gulab N. Jham, Departamento de Fitopatologia, Universidade Federal de Viçosa, 36570-000, \\ Viçosa, MG, Brazil. Tel: 55-31-3899-3071; Fax: 55-31-3899-3065. E-mail: gulab@ufv.br
}

Received: December 29, 2011 Accepted: August 17, 2013 Online Published: September 6, 2013

doi:10.5539/jfr.v2n5p124 URL: http://dx.doi.org/10.5539/jfr.v2n5p124

This research was financed by the Brazilian govt. agencies CAPES (Coordenação de Aperfeiçoamento de Pessoal de Nível Superior), CNPq (Conselho Nacional de Pesquisa) and FAPEMIG (Fundação de Amparo à Pesquisa do Estado de Minas Gerais)

\begin{abstract}
Hydrodistillation of Brazilian basil (Ocimum basilicum L.) yielded $0.4 \%$ of essential oil (EO), with activity against eight important postharvest deteriorating fungi. The crude EO completely inhibited the radial growth of the fungi at a concentration of $0.1 \%$. Thirty-two components were identified in crude EO by Kováts retention index, mass spectrometry and standards. Preparative TLC-bioautography of the crude EO presented only one band with an antifungal activity greater than that of crude EO with the following chemical composition (\%): 1,8-cineole (6.2), linalool (36.3), camphor (9.7), $\alpha$-terpineol (3.8), methyl chavicol (9.1) and eugenol (34.9). Based on these results, these compounds were considered to be the major fungitoxic components. This is the first study in the literature that presents data obtained simultaneously on the activity of crude basil EO against eight important post-harvest deteriorating fungi, its unequivocal chemical identification and quantification (area \%).
\end{abstract}

Keywords: basil, Ocimum basilicum, antifungal activity, fungitoxic components, essential oil

\section{Introduction}

Synthetic compounds presently used to manage fungi pose a challenge to control food deterioration due to their high toxicity. Hence, alternate control measures are needed and essential oils (EOs) from edible plants appear to be promising (Pawar \& Thaker, 2006, 2007; Jardim et al., 2008; Tripathi et al., 2008).

Basil (Ocimum basilicum L.) is an annual aromatic herb cultivated in several regions worldwide, being one of the most popular aromatic plants used in food seasoning. Although the basil EO chemical composition has been reported (Oxenham et al., 2005; De Masi et al., 2006; Tchoumbougnang et al., 2006; Gobbo-Neto \& Lopes, 2007; Politeo et al., 2007; Shatar et al., 2007; Chalchat \& Özcan, 2008; Hussain et al., 2008; Zheljazkov et al., 2008) with its antifungal properties (Basílico \& Basílico, 1999; Anthony et al., 2004; Oxenham et al., 2005; Soković \& Griensven, 2006; Bozin et al., 2006; Atanda et al., 2007; Herath \& Abeywickrama, 2008; Hussain et al., 2008), compounds (antifungals) responsible for the activity have not been isolated. Identification of the major antifungal compounds may lead to the discovery new antifungal compounds.

This study was conducted to assess the activities of crude Brazilian basil (O. basilicum) EO and its bioactive fraction (BAF) against the following eight postharvest deteriorating fungi: Aspergillus flavus, A. glaucus, A. niger, A. ochraceous, Colletotrichum gloesporioides, C. musae, Fusarium oxysporum and F. semitectum. In addition, the chemical compositions of the crude EO, its BAF were unequivocally determined by Kováts retention index (RI), a mass spectrometry database and standards. Components of the crude EO and the BAF were quantified by gas chromatography (GC) (relative area \%). Both data (chemical composition and antifungal) were obtained simultaneously with fresh basil EO. 


\section{Method}

\subsection{Plant Material and EO Extraction}

Shrubs were harvested in Viçosa, Minas Gerais, Brazil and identified by visually comparing freshly collected leaves with existing (registration VIC no 31879) herbalized leaves at the herbarium of Universidade Federal de Viçosa. Immediately after collection, the aerial parts were transported to the laboratory and the EO was extracted. Portions $(100 \mathrm{~g})$ of the leaves were mixed with water $(1: 10 \mathrm{w} / \mathrm{v})$ for hydrodistillation. The distillate $(800 \mathrm{ml})$ was extracted twice with dichloromethane $(5: 1 \mathrm{v} / \mathrm{v})$. The combined organic phases were dried with anhydrous sodium sulfate and filtered. Dichloromethane was evaporated in a rotary evaporator at $30^{\circ} \mathrm{C}$ under reduced pressure; the EO was weighed, stored at $4{ }^{\circ} \mathrm{C}$ in sealed ampoules, and used within a few days.

\subsection{Standards, Solvents, Materials, Reagents, and TLC Plates}

Standards (1,8-cineole, linalool, camphor, $\alpha$-terpineol, methyl chavicol and eugenol) were obtained from Sigma (St. Louis, MO). All organic solvents were of analytical grade (Vetec Química Fina, Rio de Janeiro, RJ, Brazil) and distilled before use. Pre-coated analytical $(2 \times 20 \mathrm{~cm})$ and preparative thin-layer chromatography (TLC) silica gel plates $(20 \times 20 \mathrm{~cm}, 1-\mathrm{mm}$ thick, 60 GF254) were purchased from Merck (Rio de Janeiro, Brazil). Disposable Petri dishes $(60 \times 15 \mathrm{~mm}$ and $90 \times 15 \mathrm{~mm})$ and potato-dextrose agar (PDA) were obtained from Prolab (Rio de Janeiro, Brazil).

\subsection{Identification and Quantification of the Compounds in the Crude EO}

Tentative identification of compounds in the crude EO was based on RI, GC-MS database (Adams, 2007), and by visual comparison of the mass spectra of the crude EO peaks with those stored in the database. RIs were determined on a gas chromatograph (Shimadzu, Kyoto, Japan, model GC 17A) with a flame ionization detector-FID, an auto sampler and a workstation. Gas chromatography-mass spectrometry (GC-MS) data were obtained on a gas chromatograph-mass spectrometer (Shimadzu, Kyoto, Japan, model QP 5000 software program-Classs-5000, Version 1.2) fitted with an auto sampler, workstation and a database (Wiley 229) with about 350,000 entries. Tentative identification was based on the best similarity index (SI), provided by the system software and RIs. Final identification was conducted by comparing the retention time $\left(t_{\mathrm{R}}\right)$ and relative retention time $\left(\mathrm{rt}_{\mathrm{R}}\right)$ (relative to 1,8-cineole) with standards (1,8-cineole, linalool, camphor, $\alpha$-terpineol, methyl chavicol and eugenol). Percentage of each compound was obtained by dividing the area of the peak of interest with that of the total peak area of the identified compounds and multiplying by 100. In addition, confirmation was based on spiking the crude EO with each of the six standards individually. Final identification was conducted on a Varian 8400 chromatograph with an auto sampler and a flame ionization detector. All analyses were conducted on fused silica capillary columns ( $30 \mathrm{~m}$ x $0.25 \mathrm{~mm}$ id.; $0.25 \mu \mathrm{m}$ film thickness) coated with the DB-5 stationary phase (Supelco, Bellefonte, PA). For GC, the following conditions were used: oven temperature was programmed from $60{ }^{\circ} \mathrm{C}$ ( $1 \mathrm{~min}$ hold) to $240{ }^{\circ} \mathrm{C}\left(9 \mathrm{~min}\right.$ hold) at a rate of $3{ }^{\circ} \mathrm{C} / \mathrm{min}$; the injector and the detector were maintained at 240 and $250{ }^{\circ} \mathrm{C}$, respectively. Nitrogen was used as the carrier gas at a flow of $1.3-\mathrm{ml} / \mathrm{min}$. For RI data, a mixture of linear saturated hydrocarbons was co-injected with EOs into the gas chromatograph. RIs were calculated from the following formula: RI=100y+100(z-y) $\times t_{\mathrm{R}(\mathrm{x})}-t_{\mathrm{R}(\mathrm{y})} / t_{\mathrm{R}(\mathrm{z})}-t_{\mathrm{R}(\mathrm{y})}$, where $\mathrm{y}$ and $\mathrm{z}$ are the carbon numbers of the hydrocarbons eluting before and after a peak of interest, respectively; $t_{\mathrm{R}(\mathrm{x})}$ is the retention time of the peak of interest; and $t_{\mathrm{R}(\mathrm{y})}, t_{\mathrm{R}(\mathrm{z})}$ are the retention times of the hydrocarbons eluting before and after a peak of interest, respectively.

For GC-MS analysis, the conditions used were as described for GC analysis with the transfer line maintained at $250{ }^{\circ} \mathrm{C}$ with helium as the carrier gas at a flow of $1.3-\mathrm{ml} / \mathrm{min}$. The mass spectrometer was scanned from $\mathrm{m} / \mathrm{z} 40$ to 350 in the electron impact mode $(70 \mathrm{eV})$. To obtain representative data, the mass spectra over the entire peaks ( $\sim 10$ scans) were grouped and subtracted from the grouped mass spectra of the region closest (before or after) where no compound eluted ( $\sim 50$ scans). Only compounds with SIs of $90 \%$, or over, were considered as positive identifications. A 1- $\mu$ l aliquot of the EOs dissolved in hexane (10\%) was injected in the split mode (split ratio of 20:1) with the split vent being closed for $30 \mathrm{sec}$.

\subsection{Test-Fungi}

The fungal isolates used in this study are deposited in the mycological collection of the Department of Phytopathology of the Universidade Federal de Viçosa, Viçosa, MG, Brazil. A. flavus Link (Moniliales), strain AFM 4, A. glaucus Teleomorph Eurotium (Wiggers) Link, strain AGM 9, A. niger van Tieghem (Moniliales), strain ANM 6, A. ochraceous Wilhelm (Moniliales), strain AOM 18, were isolated from maize seed. C. gloesporioides (Penz.) Sacc. (Melanoconiales), strain CGP 14, C. musae (Berk. Curt.) Arx (Melanoconiales), strain CMB 6, were isolated from papaya and banana, respectively. F. oxysporum Schlecht. Fr. (Moniliales), 
strain FSB 7, F. semitectum Wollenw (Moniliales), strain FOB 11, were isolated from bean root seed, respectively.

\subsection{Antifungal Activity of the Crude EO}

Antifungal activities were tested on PDA, using poison food assay (Dhingra \& Sinclair, 1995). A uniform dispersion was obtained by dissolving the test material in methanol $(1: 1 \mathrm{v} / \mathrm{v})$, followed by adding cool molten PDA to obtain EO concentrations of $0.1,0.09,0.08,0.075$ and $0.05 \%$. Ten- $\mathrm{ml}$ of the medium were poured into 9-cm culture plates. The medium in each plate was spot-seeded with the conidia $\left(10^{3} / \mathrm{ml}\right)$ of each fungus. Colony diameter was measured on the $6^{\text {th }}$ day after incubation at $25^{\circ} \mathrm{C}$. All tests were performed in triplicate. Percent of mycelia growth inhibition was calculated according to the equation: Inhibition $(\%)=\mathrm{dc}-\mathrm{dt} / \mathrm{dc} \mathrm{x} 100$, where $\mathrm{dc}$ and $\mathrm{dt}$ are mycelia growth diameters $(\mathrm{mm})$ in the control and treated samples. The data were analyzed by ANOVA and the means compared by the Tukey test $(p=0.05)$. The control consisted of PDA containing an equivalent amount of methanol with the EO.

\subsection{Isolation of the BAF and Determination of Its Chemical Composition and Antifungal Activities}

TLC-bioautography (Rahalison et al., 1991; Wedge \& Nagle, 2000) was used to obtain the BAF of the crude EO. Ninety milligrams of the crude basil EO were placed on each of the nine preparative pre-coated silica gel TLC plates and eluted with dichloromethane: hexane (8:2) as solvent. After elution, the plates were air dried, and sprayed with $50 \mathrm{ml}$ of molten PDA containing $100 \mathrm{mg} / 1$ streptomycin sulfate and conidia $\left(10^{3} / \mathrm{ml}\right)$ of the fungi separately. This was followed by covering the tray with a plastic film and incubation for 6 days at $25^{\circ} \mathrm{C}$. The blank was prepared in exactly the same way without the EO. The region of the TLC plates without fungal growth (bioactive fraction) was delineated with a pencil, scrapped and extracted twice by shaking for two hours with $200 \mathrm{ml}$ of dichloromethane. The combined extracts were filtered, dried over anhydrous sodium sulfate, and evaporated under a reduced pressure to obtain a residue which was weighed.

The antifungal activity and the chemical composition of the BAF were determined as described for the crude EO.

\subsection{Statistical Analysis}

Percent radial growth inhibition reported is the average of three replications. The data were analyzed by ANOVA and the results statistically evaluated by the Tukey test $(\mathrm{P}=0.05)$.

\section{Results}

\subsection{Essential Oil Yield}

Hydrodistillation of the $O$. basilicum leaves yielded $0.4 \%$ EO (fresh weight basis) (Table 1).

\subsection{Chemical Composition of the Crude EO and Its Antifungal Activity}

The crude EO presented the following percentage composition of the six major compounds (elution order) corresponding to $81.4 \%$ of the total chromatographic peak area: 1,8-cineole (16.6), linalool (28.0), camphor (10.7), eugenol (18.4), germacrene D (4.6) and $\alpha$-murolol (3.1) (Tables 1 and 2, Figure 1A).

Of the remaining area, $15.8 \%$ was made up by twenty-six constituents with relative concentration of less than $3 \%$ and the remaining compounds $(2.8 \%$ of the area) could not be identified by the mass spectral database. Of the thirty-two compounds $(97.2 \%$ of the total chromatographic peak area) tentatively identified, the presence of six compounds (1,8-cineole, linalool, camphor, $\alpha$-terpineol, methyl chavicol and eugenol), corresponding to $77.5 \%$ of the total chromatographic peak area, was confirmed by commercially available standards.

Sensitivity to the crude EO varied with the fungal species. The crude EO completely inhibited the radial growth of all the eight fungi at a concentration of $0.1 \%$. At other concentrations, the activity depended on the fungus. For instance, at a concentration of $0.09 \%$, inhibition of A. flavus, A. glaucus, A. niger, A. ocrhaceous, C. gloesporioides, C. musae, F. oxysporum, F. semitectum was 72, 90, 78, 78, 100, 96, 95 and 95\%, respectively. At concentrations of $0.80,0.075$ and $0.05 \%$, the inhibition decreased consistently for all fungi. 

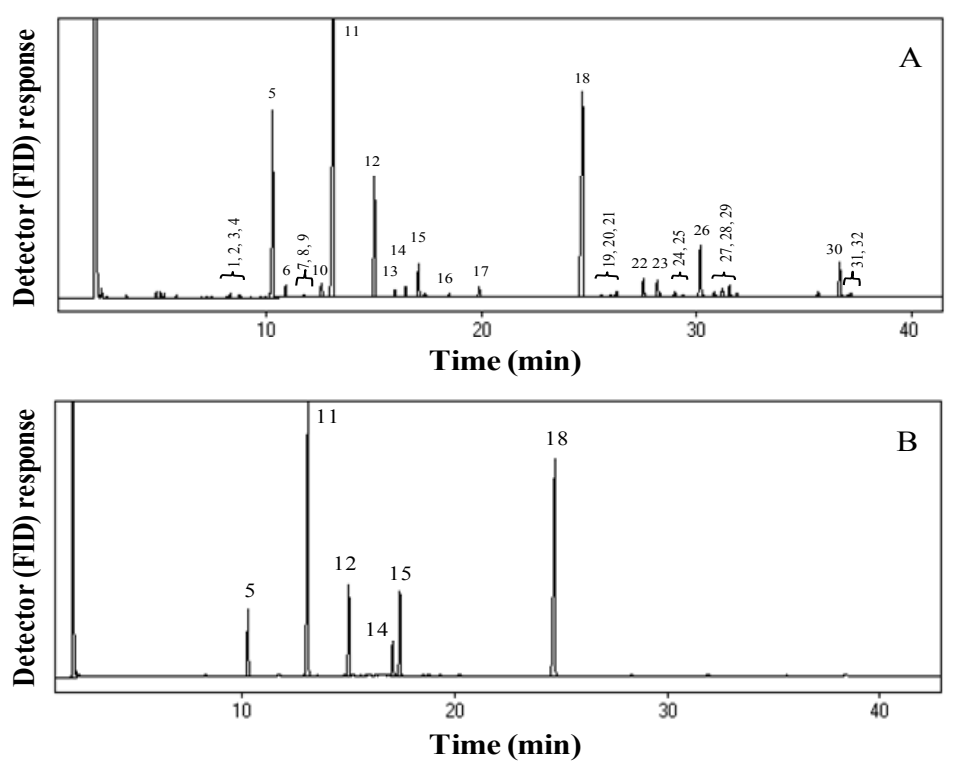

Figure 1. Gas chromatograms obtained on analysis of crude EO (A) and the bioactive fraction (B) of the Brazilian Ocimum basilicum essential oil. Chromatographic conditions were: oven temperature programmed from $60{ }^{\circ} \mathrm{C}(1 \mathrm{~min}$ hold $)$ to $240{ }^{\circ} \mathrm{C}(9 \mathrm{~min}$ hold $)$ at $3{ }^{\circ} \mathrm{C} \mathrm{min}^{-1} ; \mathrm{N}_{2}$ carrier gas $\left(1.3 \mathrm{ml} \mathrm{min}{ }^{-1}\right)$, temperatures of the injector and the detector 220 and $240^{\circ} \mathrm{C}$, respectively, with a fused silica capillary column coated with the DB-5

stationary phase. Peaks 1-32 identified in the chromatograms refer to the compounds listed in Table 2

Table 1. Percentage yields and compositions of the major components of basil essential oil (EO) reported from some countries

\begin{tabular}{|c|c|c|c|}
\hline Country & Yield (\%) & Composition (\%) of the major components & Reference/Comment \\
\hline $\begin{array}{c}\text { Serbia } \\
\text { Montenegro }\end{array}$ & 0.37 & Chavicol (45.8) and linalool (24.2) & Bozin et al., 2006 \\
\hline Italy & $\begin{array}{l}\text { Not } \\
\text { reported }\end{array}$ & $\begin{array}{c}\text { Linalool ( } 33.5 \text { to } 63.6) \text { for all cultivars, except one } \\
\text { with } 6.2 \% \text { and eugenol ( } 0.3 \text { to } 17.9)\end{array}$ & De Masi et al., 2006 \\
\hline $\begin{array}{l}\text { Several } \\
\text { countries } \\
\text { from Africa }\end{array}$ & $0.02-1.3$ & $\begin{array}{c}\text { Linalool (46.0), limonene (17.1), 1,8-cineole (8.5), } \\
\text { terpin-4-ol (3.6) (Cameroon) }\end{array}$ & $\begin{array}{l}\text { Tchoumbougnang et al., } \\
2006\end{array}$ \\
\hline $\begin{array}{l}\text { Brazil } \\
\text { (northeastern } \\
\text { state of } \\
\text { Ceara) }\end{array}$ & 3.0 & $\begin{array}{l}\text { Linalool (42.5), methyl chavicol (33.1) and } \\
\text { 1,8-cineole (11.0) }\end{array}$ & Trevisan et al., 2006 \\
\hline $\begin{array}{c}\text { Brazil } \\
\text { (northeastern } \\
\text { state of } \\
\text { Sergipe) }\end{array}$ & $\begin{array}{l}\text { Not } \\
\text { reported }\end{array}$ & $\begin{array}{l}\text { Linalool (69.3), eugenol (10.8) and } \\
\alpha \text {-trans-bergamotene (7.7) }\end{array}$ & Almeida et al., 2007 \\
\hline $\begin{array}{l}\text { Brazil } \\
\text { (southeastern } \\
\text { state of Minas } \\
\text { Gerais) }\end{array}$ & $\begin{array}{l}\text { Not } \\
\text { reported }\end{array}$ & $\begin{array}{l}\text { Linalool (47.0), 1,8-cineole (15.0) and camphor } \\
\qquad(9.5)\end{array}$ & Santoro et al., 2007 \\
\hline Turkey & 1.0 & $\begin{array}{l}\text { Methyl chavicol (52.6), limonene (13.6), } \\
\text { exo-fenchyle acetate (11.0), fenchone (5.7), } \\
\alpha \text {-phellendrene (4.1) and } p \text {-cymene (2.3) }\end{array}$ & Chalchat \& Özcan, 2008 \\
\hline Pakistan & $0.5-0.8$ & $\begin{array}{c}\text { Linalool (56.7-60.6\%), epi- } \alpha \text {-cadinol }(8.6-12.4 \%) \text {, } \\
\alpha \text {-bergamotene }(7.4-9.2 \%) \text { and } \gamma \text {-cadinene } \\
(3.2-5.4 \%)\end{array}$ & Hussain et al., 2008 \\
\hline $\begin{array}{l}\text { Brazil } \\
\text { (southeastern } \\
\text { state of Minas } \\
\text { Gerais) }\end{array}$ & 0.4 & $\begin{array}{c}\text { 1,8-cineole (16.6), linalool (28), camphor (10.7) } \\
\text { and eugenol (18.4) }\end{array}$ & $\begin{array}{l}\text { Results of this study with } \\
\text { the presence of all the } \\
\text { four major components } \\
\text { confirmed by standards }\end{array}$ \\
\hline
\end{tabular}


Table 2. Percent composition of the crude essential oil (EO) of the Brazilian basil (Ocimum basilicum) and the bioactive fraction (BAF) based on Kováts retention index (RI), mass spectrometry database and a visual comparison of the mass spectra of the sample peaks with those stored in the mass spectral database along with authentic standards

\begin{tabular}{|c|c|c|c|c|}
\hline \multirow{2}{*}{$\begin{array}{l}\text { Peak no. } \\
\text { (Figure 1) }\end{array}$} & \multirow{2}{*}{ Retention index (RI) } & \multirow{2}{*}{ Compounds } & \multicolumn{2}{|c|}{ Composition (\%) } \\
\hline & & & Crude EO & BAF \\
\hline 1 & 977 & Sabinene & 0.1 &.- \\
\hline 2 & 979 & $\beta$-Pinene & 0.2 & - \\
\hline 3 & 981 & Octen-3-ol & 0.3 & - \\
\hline 4 & 992 & Myrcene & 0.2 & - \\
\hline 5 & 1035 & 1,8-Cineole* & $16.6^{*}$ & 6.2 \\
\hline 6 & 1051 & $(E)-\beta$-Ocimene & 1.0 & - \\
\hline 7 & 1063 & $\gamma$-Terpinene & 0.1 & - \\
\hline 8 & 1070 & Cis-sabinene hydrate & 0.1 & - \\
\hline 9 & 1072 & Octanol & 0.2 & - \\
\hline 10 & 1089 & Fenchone & 1.2 & - \\
\hline 11 & 1100 & Linalool* & $28.0^{*}$ & 36.3 \\
\hline 12 & 1151 & Camphor* & $10.7^{*}$ & 9.7 \\
\hline 13 & 1174 & Terpin-4-ol & 0.6 & - \\
\hline 14 & 1186 & $\alpha$-Terpineol* ${ }^{*}$ & $0.9^{*}$ & 3.8 \\
\hline 15 & 1198 & Methyl chavicol* & $2.9^{*}$ & 9.1 \\
\hline 16 & 1259 & Chavicol & 0.9 & - \\
\hline 17 & 1291 & Isobornyl acetate & 0.1 & - \\
\hline 18 & 1365 & Eugenol* & $18.4^{*}$ & 34.9 \\
\hline 19 & 1386 & $\alpha$-Copaene & 0.2 & - \\
\hline 20 & 1395 & $\beta$-Bourbonene & 0.2 & - \\
\hline 21 & 1402 & $\beta$-Elemene & 0.5 & - \\
\hline 22 & 1429 & (E)-Caryophyllene & 1.6 & - \\
\hline 23 & 1444 & $\alpha$-Trans-Bergamotene & 1.5 & - \\
\hline 24 & 1447 & $\alpha$-Guaiene & 0.3 & - \\
\hline 25 & 1462 & $\alpha$-Humulene & 0.5 & - \\
\hline 26 & 1485 & Germacrene D & 4.6 & - \\
\hline 27 & 1498 & Bicyclogermacrene & 0.4 & - \\
\hline 28 & 1516 & $\gamma$-Cadinene & 1.0 & - \\
\hline 29 & 1526 & $\Delta$-Cadinene & 0.3 & - \\
\hline 30 & 1645 & $\alpha$-Murolol & 3.1 & - \\
\hline 31 & 1648 & (Z)-Methyl jasmonate & 0.3 & - \\
\hline 32 & 1658 & Bulnesol & 0.3 & - \\
\hline & Total identifi & & $\begin{array}{c}97.2 \\
\left(77.5^{*}\right)\end{array}$ & 100.0 \\
\hline
\end{tabular}

*Confirmed by standards.

\subsection{Chemical Composition of the BAF and Its Antifungal Activity}

The BAF isolated from the crude EO presented the following \% composition, corresponding to $100 \%$ of the total chromatographic peak area: 1,8-cineole (6.2), linalool (36.3), camphor (9.7), $\alpha$-terpineol (3.8), methyl chavicol (9.1) and eugenol (34.9) (Figure 1B).

The sensitivity to the purified EO fraction varied with the fungal species. The crude EO completely inhibited the radial growth of all the eight fungi at concentrations of 0.1 and $0.09 \%$. However, at other concentrations, the activity varied with concentration. For instance, at a concentration of $0.080 \%$, percentage inhibition was almost complete for all the fungi studied. 


\section{Discussion}

Yields and percentage compositions of the major components of basil EO from several countries are reported in Table 1. As it can be noted, the EO yields obtained in this study were different from that reported in studies in other countries, including from Brazil. EO yield (0.4\%) obtained in this study was much lower than the $3 \%$ yield reported in one Brazilian study (Trevisan et al., 2006) while yields were not reported in the other two studies in Brazil (Almeida et al., 2007; Santoro et al., 2007). Variations in EO yield and composition were expected as they are affected by several factors such as genotype, agro climatic conditions, solar irradiance level, etc. (Gobbo-Neto \& Lopes, 2007; Hussain et al., 2008; Chang et al., 2008).

A typical gas chromatogram obtained on analysis of the crude EO and the BAF is presented in Figure 1. The chemical composition was quite different from that reported from other countries (Tables 1 and 2), including Brazil (Trevisan et al., 2006; Almeida et al., 2007; Santoro et al., 2007). In all the Brazilian studies, except ours, identification of the EO components was not confirmed by standards and, hence, not reliable. It is interesting to note that all the compounds identified tentatively in this study were confirmed by standards. This is the first study in the literature where the crude EO was fractionated, identified and quantified.

Chemical compositions of the basil EOs reported in the literature were based only on RI and on a mass spectral database without standards (Herath \& Abeywickrama, 2008). However, standards were used for confirmation in a few studies (Oxenham et al., 2005; Zheljazkov et al., 2008). While identification based on RI and mass spectral databases is very widely used for volatiles (Adams, 2007), it is well known that it is tentative and must be confirmed by standards.

In our study, we obtained a good antifungal activity against eight post-harvest fungi, with activity being shown for the first time in a few cases. Antifungal activity of basil EO has been reported by other authors. Complete inhibition of A. ochraceous was reported at a concentration of $0.1 \%$ (Basílico \& Basílico, 1999). Basil EO and several of its pure components (methyl chavicol, linalol, eugenol and caryophyllene) presented activity against Botrytis fabae and Uromyces fabae (Oxenham et al., 2005). An emulsion spray (0.16\%) of the Indian basil was effective in controlling crown rot in banana (Herath \& Abeywickrama, 2008). Basil EO showed an inhibitory effect on A. niger (Pawar \& Thaker, 2006), F. oxysporum (Pawar \& Thaker, 2007), A. flavus and A. ochraceous (Soliman \& Badeaa, 2002). However, the chemical composition of the EO was not reported in these studies. $O$. basilicum oil containing linalool (69.3\%) showed activity against Verticillium fungicola and Trichoderma harzianum at concentrations varying between 1.5-2.0\% (Soković \& Griensven, 2006). On the other hand, basil EO containing methyl chavicol $(45.8 \%)$ and linalool $(24.2 \%)$ as the major constituents showed a weak antimicrobial activity (Bozin et al., 2006). A. niger, Mucor mucedo, F. solani, Botryodiplodia theobromae, Rhizopus solani were affected by linalool (Hussain et al., 2008). Sensitivity of A. flavus and A. ochraceous to basil EO is of particular interest since they produce potentially carcinogenic mycotoxins in grain and feed they colonize. This EO can be a good candidate for use in such products, being considered safe for human consumption when appropriately used (Fandohan et al., 2008).

Major fungitoxics of the basil EO have not been isolated nor characterized. In this study, it was possible to quickly identify, for the first time, the major fungitoxics in the BAF using TLC-bioautography. In this technique, a crude EO is separated by conventional preparative TLC and then sprayed with a fungal suspension of interest followed by incubation for several days. "Clear zones" on the sprayed TLC plates, which suggest presence of antifungals, are scrapped from the plate, extracted by an organic solvent and identified. Despite being a convenient technique offering a great potential, TLC-bioautography is little used. Through this technique we have identified and quantified the following major fungitoxics in the crude EO: 1,8-cineole, linalool, camphor, $\alpha$-terpineol, methyl chavicol, and eugenol. However, the participation of other compounds cannot be excluded.

\section{Conclusion}

This is the first study in the literature where the chemical composition of the Brazilian basil EO was unequivocally determined simultaneously with antifungal activity and characterization of the BAF. The information generated in this study will be useful for further studies in our laboratory as well as to laboratories worldwide.

\section{References}

Adams, R. P. (2007). Identification of essential oil components by gas chromatography/mass spectroscopy (4th ed.). Carol Stream: Allured.

Almeida, I., Alviano, D. S., Vieira, D. P., Alves, P. B., Blank, A. F., Lopes, A. H. C. S., ... Rosa, M. S. S. (2007). Antigiardial activity of Ocimum Basilicum essential oil. Parasitology Research, 101, 443-452. 
http://dx.doi.org/10.1007/s00436-007-0502-2

Anthony, S., Abeywickrama, K., Dayananda, R., Wijeratnam, S. W., \& Arambewela, L. (2004). Fungal pathogens associated with banana fruit in Sri Lanka, and their treatment with essential oils. Mycopathologia, 157, 91-97. http://dx.doi.org/10.1023/B:MYCO.0000012226.95628.99

Atanda, O. O., Akpan, I., \& Oluwafemi, F. (2007). The potential of some spice essential oils in the control of $A$. parasiticus CFR 223 and aflatoxin production. Food Control, 18, 601-607. http://dx.doi.org/10.1016/j.foodcont.2006.02.007

Basílico, M. Z., \& Basílico, J. C. (1999). Inhibitory effects of some spice essential oils on Aspergillus ochraceus NRRL 3174 growth and ochratoxin A production. Letters in Applied Microbiology, 29, 238-241. http://dx.doi.org/10.1046/j.1365-2672.1999.00621.x

Bozin, B., Mimica-Dukic, N., Simin, N., \& Anackov, G. (2006). Characterization of the volatile composition of essential oils of some Lamiaceae spices and the antimicrobial and antioxidant activities of the entire oils. Journal of Agricultural and Food Chemistry, 54, 1822-1828. http://dx.doi.org/10.1021/jf051922u

Chalchat, J., \& Özcan, M. M. (2008). Comparative essential oil composition of flowers, leaves and stems of basil (Ocimum basilicum L.) used as herb. Food Chemistry, 110, 501-503. http://dx.doi.org/10.1016/j.foodchem.2008.02.018

Chang, X., Alderson, P. G., \& Wright, C. J. (2008). Solar irradiance level alters the growth of basil (Ocimum basilicum L.) and its content of volatile oils. Environmental and Experimental Botany, 63, 216-223. http://dx.doi.org/10.1016/j.envexpbot.2007.10.017

De Masi, L., Siviero, P., Esposito, C., Castaldo, D., Siano, F., \& Laratta, B. (2006). Assessment of agronomic, chemical and genetic variability in common basil (Ocimum basilicum L.). European Food Research and Technology, 223, 273-281. http://dx.doi.org/10.1007/s00217-005-0201-0

Dhingra, O. D., \& Sinclair, J. B. (1995). Basic Methods in plant pathology. Boca Raton: CRC.

Fandohan, P., Gnonlonfin, B., Laleye, A., Gbenou, J. D., Darboux, R., \& Moudachirou, M. (2008). Toxicity and gastric tolerance of essential oils from Cymbopogon citratus, Ocimum gratissimum and Ocimum basilicum in Wistar rats. Food and Chemical Toxicology, 46, 2493-2497. http://dx.doi.org/10.1016/j.fct.2008.04.006

Gobbo-Neto, L., \& Lopes, N. P. (2007). Plantas medicinais: fatores de influência no conteúdo de metabólitos secundários. Quimíca Nova, 30, 374-381. http:doi.org/10.1590/S0100-40422007000200026

Herath, H., \& Abeywickrama, K. (2008). In vitro application of selected essential oils and their major components in controlling fungal pathogens of crown rot in Embul Banana (Musa acuminata AAB). International Journal of Food Science and Technology, 43, 440-447. http://dx.doi.org/10.1111/j.1365-2621.2006.01465.x

Hussain, A. I., Anwar, F., Sherazi, S. T. H., \& Przybylski, R. (2008). Chemical composition, antioxidant and antimicrobial activities of basil (Ocimum basilicum) essential oils depends on seasonal variations. Food Chemistry, 108, 986-995. http://dx.doi.org/10.1016/j.foodchem.2007.12.010

Jardim, C. M., Jham, G. N., Dhingra, O. D., \& Freire, M. M. (2008). Composition and antifungal activity of the essential oil of the Brazilian Chenopodium ambrosioides L. Journal of Chemical Ecology, 34, 1213-1218. http://dx.doi.org/10.1007/s10886-008-9526-z

Oxenham, S. K., Svoboda, K. P., \& Walters, D. R. (2005). Antifungal activity of the essential oil of basil $\begin{array}{lllll}\text { (Ocimum basilicum). Journal of } & \text { Phytopathology, } & 153, & \text { 174-180. }\end{array}$ http://dx.doi.org/10.1111/j.1439-0434.2005.00952.x

Pawar, V. C., \& Thaker, V. S. (2006). In vitro efficacy of 75 essential oils against Aspergillus niger. Mycoses, 49, 316-323. http://dx.doi.org/10.1111/j.1439-0507.2006.01241.x

Pawar, V. C., \& Thaker, V. S. (2007). Evaluation of the anti-Fusarium oxysporum f. sp cicer and anti-Alternaria porri effects of some essential oils. World Journal of Microbiology and Biotechnology, 23, 1099-1106. http://dx.doi.org/10.1007/s11274-006-9339-6

Politeo, O., Jukic, M., \& Milos, M. (2007). Chemical composition and antioxidant capacity of free volatile aglycones from basil (Ocimum basilicum L.) compared with its essential oil. Food Chemistry, 101, 379-385. http://dx.doi.org/10.1016/j.foodchem.2006.01.045

Rahalison, L., Hamburger, M., Hostettmann, K., Monod, M., \& Frenk, E. A. (1991). Bioautographic agar overlay 
method for the detection of antifungal compounds higher plants. Phytochemical Analysis, 2, 199-203. http://dx.doi.org/10.1002/pca.2800020503

Santoro, G. F., Cardoso, M. G., Guimarães, L. G. L., Mendonça, L. Z., \& Soares, M. J. (2007). Trypanosoma cruzi: activity of essential oils from Achillea millefolium L., Syzygium aromaticum L. and Ocimum basilicum L. on epimastigotes and trypomastigotes. Experimental Parasitology, 116, 283-290. http://dx.doi.org/10.1016/j.exppara.2007.01.018

Shatar, S., Altantsetseg, S., Sarnai, I., Zoljargal, D., Thang, T. D., \& Dung, N. X. (2007). Chemical composition of the essential oil of Ocimum Basilicum cultivated in Mongolian Desert-Gobi. Chemistry of Natural Compounds, 43, 726-727. http://dx.doi.org/10.1007/s10600-007-0247-2

Soković, M., \& Griensven, L. (2006). Antimicrobial activity of essential oils and their components against the three major pathogens of the cultivated button mushroom, Agaricus bisporus. European Journal of Plant Pathology, 116, 211-224. http://dx.doi.org/10.1007/s10658-006-9053-0

Soliman, K. M., \& Badeaa, R. I. (2002). Effect of oil extracted from some medicinal plants on different mycotoxigenic fungi. Food Chemistry and Toxicolology, 40, 1669-1675. http://dx.doi.org/10.1016/S0278-6915(02)00120-5

Tchoumbougnang, F., Zollo, P. H. A., Avlessi, F., Alitonou, G. A., Sohounhloue, D. K., Ouamba, J. M., ... Menut, C. (2006). Variability in the chemical composition of the essential oils of five Ocimum species from Tropical African area. Journal of Essential Oil Research, 18, 194-199. http://dx.doi.org/10.1080/10412905.2006.9699064

Trevisan, M. T. S., Silva, M. G. V., Pfundstein, B., Spiegelhalder, B., \& Owen, R. W. (2006). Characterization of the volatile pattern and antioxidant capacity of essential oils from different species of the genus Ocimum. Journal of Agricultural and Food Chemistry, 54, 4378-4382. http://dx.doi.org/10.1021/jf060181+

Tripathi, P., Dubey, N., \& K. Shukla, A. K. (2008). Use of some essential oils as post-harvest botanical fungicides in the management of grey mould of grapes caused by Botrytis cinerea. World Journal of Microbiology and Biotechnology, 24, 39-46. http://dx.doi.org/10.1007/s11274-007-9435-2

Wedge, D. E., \& Nagle, D. G. (2000). A new 2D-TLC bioautography method for the discovery of novel antifungal agents to control plant pathogens. Journal of Natural Products, 63, 1050-1054. http://dx.doi.org/10.1021/np990628r

Zheljazkov, V. D., Callahan., A., \& Cantrell, C. L. (2008). Yield and oil composition of 38 basil (Ocimum basilicum L.) accessions grown in Mississippi. Journal of Agricultural and Food Chemistry, 56, 241-245. http://dx.doi.org/10.1021/jf072447y

\section{Copyrights}

Copyright for this article is retained by the author(s), with first publication rights granted to the journal.

This is an open-access article distributed under the terms and conditions of the Creative Commons Attribution license (http://creativecommons.org/licenses/by/3.0/). 